\title{
Pengaruh Bagi Hasil Terhadap Minat Nasabah Pada Tabungan BSM di Bank Syariah Mandiri Muara Bungo
}

\author{
Abdul Roni \\ Universitas Islam Negeri Sunan Kalijaga Yogyakarta \\ Email: abdulrony555@gmail.com
}

\begin{abstract}
Abstrak
Perkembangan Bank Syari'ah di Indonesia tergolong meningkat pesat, banyak bankbank yang semula bersifat komersial akhirnya membuka cabang perbankan yang bersifat Syari'ah. Perusahaan-perusahaan perbankan tersebut bukanlah hanya sekedar mencoba untuk mengembangkan prinsip Syari'ah di Indonesia, tetapi faktor yang lebih penting adalah permintaan konsumen untuk dibentuknya perbankan Syari'ah. Pada akhirnya sangat diperlukan suatu penelitian untuk mengetahui seberapa besar partisipasi dan kontribusi masyarakat menabung di Bank Syari'ah, dalam hal ini peneliti akan meneliti di bank syariah mandiri di Muara Bungo dengan judul penelitian Pengaruh Bagi Hasil Terhadap Minat Nasabah Pada Tabungan BSM Di Bank Syariah Mandiri Muara Bungo. Penelitian ini menggunakan pendekatan Deskriftif Kuantitatif. Populasi penelitian ini adalah 6000 nasabah Bank Syari'ah Mandiri Muara Bungo. Teknik pengambilan sampel, menggunakan rumus Slovin terdapat jumlah sampel sebanyak 99 responden (nasabah). Teknik pengumpulan data menggunakan kuesioner sebanyak 14 item, pernyataan yang dinilai dengan skala Likert 5-1 serta menggunakan uji validitas, reliabilitas dan uji normalitas. Teknik analisis data untuk menjawab hipotesis menggunakan analisis regresi sederhana dan uji parsial. Hasil penelitian ini adalah, Berdasarkan analisis regresi pada taraf signifikan 5\%, dengan koefisien korelasi $\mathrm{R}$ sebesar 0,282, (28,2\%) koefesiaen deteriminasi sebesar $0,079,(7,9 \%)$ nilai signifikansi $0,005<0,05$; dan $\mathrm{t}$ hitung $>$ dari $\mathrm{t}$ tabel $(2,890>1,985) \mathrm{Hal}$ ini menunjukkan terdapat pengaruh positif dan signifikan Bagi Hasil terhadap Minan Nasabah Pada Tabungan BSM Bank Syari'ah Mandiri Muara Bungo. Persentase sumbangan pengaruh variabel independen (bagi hasil Bank Syari'ah) terhadap variabel dependen (tabungan BSM) sebesar 7,9\%, sedangkan $92,1 \%$ dipengaruhi atau dijelaskan oleh variabel lain.
\end{abstract}

Keywords: Mudharabah, Minat Nasabah, dan Tabungan BSM

\begin{abstract}
The development of Sharia Banks in Indonesia is classified as rapidly increasing, many banks that were originally commercial in nature eventually opened sharia banking branches. These banking companies are not just trying to develop Sharia principles in Indonesia, but a more important factor is consumer demand for the establishment of Sharia banking. In the end, a research is needed to find out how much participation and contribution of the community to save in Syari'ah Bank, in
\end{abstract}

Nur El-Islam, Volume 6, Nomor 2, Oktober 2019 
this case researchers will examine in an independent Islamic bank in Muara Bungo with the title of research on "The Effect of Revenue Sharing on Customer Interest in BSM Savings in Mandiri Syariah Bank Muara Bungo. This research uses a quantitative descriptive approach. The population of this research is 6000 customers of Bank Syari'ah Mandiri Muara Bungo. The sampling technique, using the Slovin formula there are a total sample of 99 respondents (customers). Data collection techniques used a questionnaire of 14 items, statements rated by a 5-1 Likert scale and using validity, reliability and normality tests. Data analysis techniques to answer hypotheses using simple regression analysis and partial tests. The results of this study are, Based on the regression analysis at a significant level of $5 \%$, with a correlation coefficient $\mathrm{R}$ of 0.282 , $(28.2 \%)$ deterimination coefficient of 0.079 , $(7.9 \%)$ significance value of $0.005<0.05$; and $t$ arithmetic $>$ from $t$ table $(2,890>1,985)$ This shows that there is a positive and significant effect on the Profit Sharing of the Customer Minan at the BSM Savings Bank Mandiri Sharia Muara Bungo. The percentage contribution of the influence of the independent variable (Sharia Bank profit sharing) to the dependent variable (BSM savings) was $7.9 \%$, while $92.1 \%$ was influenced or explained by other variables.

Keywords: Profit Sharing, Customer Interests, and BSM Savings

\section{A. Pendahuluan}

1. Latar Belakang

Perkembangan perbankan syari'ah pada era reformasi ditandai dengan disetujuinya undang-undang No. 10 Tahun 1998. Dalam undang-undang tersebut diatur dengan rinci landasan hukum serta jenis-jenis usaha yang dapat dioperasikan dan diimplementasikan oleh Bank Syari'ah. Undang-undang tersebut juga memberikan arahan bagi bank-bank konvensional untuk membuka cabang Syari'ah atau bahkan mengkonversikan diri secara total menjadi Bank Syari'ah.

"Lahirnya UU No 7 Tahun 1992 dan UU No 10 Tahun 1998 tentang eksistensi Bank Syari'ah, memicu tumbuhnya bank-bank Syari'ah di Indonesia, antara lain Bank Syari'ah Mandiri, Dan untuk lebih merangsang serta lebih memperjelas kegiatan perbankan Syari'ah. Pada tahun 1998 dikeluarkan UU No 10 Tahun 1998 sebagai amandemen UU No 7 Tahun 1992. Kesempatan ini dimanfaatkan oleh bank konvensional untuk mengkonversikan diri secara penuh menjadi bank umum Syari'ah maupun membuka kantor cabang Syari'ah.”1

${ }^{1}$ Republik Indonesia. “Undang-Undang R.I. Nomor 10 Tahun 1998 Tentang Perbankan Syariah”, Perubahan Atas Undang-Undang Nomor 7 Tahun 1992 Tentang Perbankan. Ketentuan Umu ,( Jakarta: 1998), h. 3. 
Undang-undang tersebut juga memberikan arahan bagi bankbank konvensional untuk membuka cabang Syari'ah atau bahkan mengkonversi diri secara total menjadi Bank Syari'ah. Peluang tersebut ternyata disambut antusias oleh masyarakat perbankan, sejumalah bank mulai memberikan pelatihan dalam bidang perbankan Syari'ah bagi para stafnya. Sebagian bank tersebut ingin menjajaki untuk membuka defisi atau cabang Syari'ah dalam institusinya, sebagian lainnya bahkan berencana mengkonversi diri sepenuhnya menjadi Bank Syari'ah.

"Bank adalah badan usaha yang menghimpun dana dari masyarakat dalam bentuk Simpanan dan menyalurkannya kepada masyarakat dalam bentuk kredit atau bentuk lainnya, dalam rangka meningkatkan taraf hidup rakyat". ${ }^{2}$ Menjalankan peran bank sebagai perantara keuangan, maka penghimpunan dana merupakan aktivitas utama yang dilakukan sebelum menyalur dana kepada masyarakat.

"Menyimpan uang di Bank Syari'ah termasuk kategori investasi. Besar kecilnya perolehan return tergantung pada hasil usaha yang benarbenar terjadi dan dilakukan oleh bank sebagai pengelola dana. Oleh karena itu, Bank Syari'ah atau lembaga keuangan syri'ah tidak hanya sekedar menyalurkan uang, tetapi harus terus- menerus berusaha meningkatkan return on investement nya yang berupa tingkat bagi hasil, sehingga lebih menarik dan lebih memberikan kepercayaan bagi pemilik dana. Dan pada akhirnya persaingan perbankan mana yang dapat memberikan return dan pelayanan lebih baik." 3

Kesempatan dan peluang bagi masyarakat untuk bisa berinvestasi di bank syariah di Muara Bungo yaitu di Bank Syariah Mandiri BSM sangat terbuka bagi msyarakat mengabil bagian berinvestasi dalam mengembangkan Bank Syariah Mandiri, kemajuan dan kemunduran perbankan syariah tergantung seberapa besar

${ }^{2}$ M.Faisal Abdullah. Manajemen Perbankan Teknis Analisi Kinerja Keuangan Bank, (Malang: UMM, 2003), cet. 3. h. 20.

${ }^{3}$ Adiwarman A. Karim, Bank Islam: Analisis Fiqih dan Keuangan, (Jakarta: PT Raja Grafindo Persada, 2010), h. 387. 
masyarakat dalam berpartisipasi, berintraksi dan berinvestasi di bank syariah.

Grafik 1. Jaringan Kantor Individual Bank Syariah Mandiri tahun 2010-2017

$\square \mathrm{KPO} / \mathrm{KC} / \mathrm{HOO} / \mathrm{BO} \quad \mathrm{KCP} / \mathrm{UPSSBO} / \mathrm{SSU}=\mathrm{KK} / \mathrm{CO}$

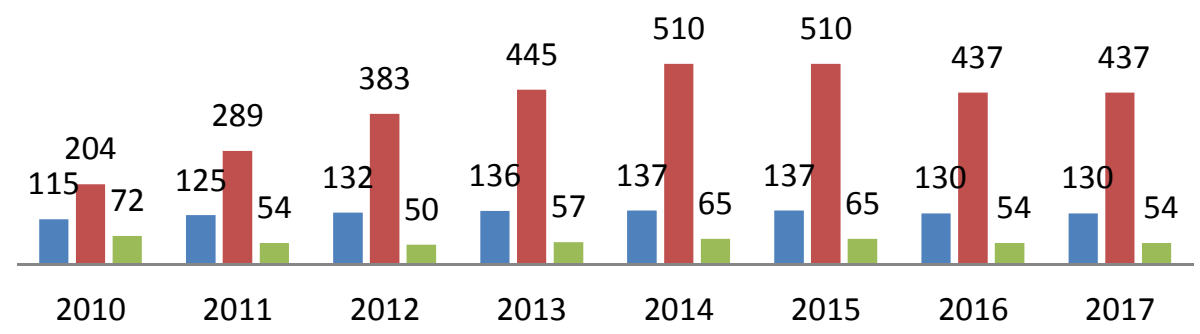

$$
\begin{array}{ll}
\mathrm{KPO} & =\text { Kantor Pusat Operasional } \\
\mathrm{KC} & =\text { Kantor Cabang } \\
\mathrm{HOO} & =\text { Head Operational Office } \\
\mathrm{BO} & =\text { Branch Office } \\
\mathrm{KCP} & =\text { Kantor Cabang Pembantu } \\
\mathrm{UPS} & =\text { Unit Pelayanan Syariah } \\
\mathrm{SBO} & =\text { Sub Branch Office } \\
\mathrm{SSU} & =\text { Sharia Services Unit } \\
\mathrm{KK} & =\text { Kantor Kas } \\
\mathrm{CO} & =\text { Cash Office }
\end{array}
$$

Sumber: OJK Statistik Perbankan Syariah

Dari grafik diatas tersebut dapat lihat, mengambarkan bahwa perkembangan bank syariah mandiri BSM dari tahun 2010 -2014 mengalami peningkatan yang signifikan. Pada tahun 2014-2015 bahwa perkembangan bank syariah mandiri mengalami konstan. Tahun 20152017 mengalmai penurunan hal ini menunjukan bahwa BSM butuh partisipasi dari masyarakat guna meningkatkan perkebangna BSM. Hal 
ini sejalan dengan penelitian Edwin Prasstio "bahwa penurunan partisipasi masyarakat tersebut dikarenakan masyarakat menabung di perbankan syariah kurang menguntungkan dibandingkan dengan Konvensional". 4

Perbankan Syari'ah mengalami pertumbuhan yang pesat, dalam rangka mengekspansikan perkembangan Bank. Secara golabal perbankan Syari'ah mengalami perkembangan yang sangat pesat, hal ini dapat dilihat dari jumlah kantor cabang yang terdapat diberbagai daerah, akan tetapi secara deduktif perkembangan perbankan Syari'ah sangat lambat, ini menunjukan aktivitas Bank Syari'ah sebagai penghimpun dana dari masyarakat, kemudian menyalurkan kepada masyarakat dalam bentuk pembiayaan atau lainnya belum berjalan dengan maksimal.

Semejak BSM berdiri dana awal yang dikelola oleh Bank Syari'ah mandiri sebesar 72 Milyar Rupiah. Dengan sejumlah dana yang dikelolah oleh Bank Syari'ah mandiri Muara Bungo sangatlah minim sekali untuk mengembangakan perbankan Syari'ah untuk lebih maju lagi, tentu dana dari masyarakat (nasabah) yang menabung di perbankan Syari'ah sangat membantu untuk perkembangan BSM dimasa yang akan datang. ${ }^{5}$

Oleh sebab itu berdasarkan permasalahan yang telah diuraikan di atas maka penulis tertarik untuk melihat seberapa besar Pengaruh Bagi Hasil Terhadap Minat Nasabah Pada Tabungan BSM di Bank Syariah Mandiri Muara Bungo.

\section{Identifikasi Masalah}

Dibagian latar belakang masalah tersebut, maka peneliti mengedintifikasikan. Bahwa masalah yang terjadi dilapangan adalah partisipasi masyarakat terhadap perbankan syariah Muara Bungo

${ }^{4}$ Edwin Prasstio, Pengaruh Tingkat Nisbah Bagi Hasil, Penerapan Akad, Citra Merek, Promosi, Dan Kualitas Pelayanan Terhadap Minat Menabung Pada Lembaga Keuangan Perbankan Syariah (Skripsi UIN Syarif Hidayatullh 2017), h. 94.

${ }^{5}$ Wawancara Dengan Fajri Kanda Branch Operation and Service Manager, Ari. A. Irawan Micro Banking Manager dan Sandy Kurniadi Mantan Customer Service. Bank Syariah mandiri Muara Bungo, (23 Agustus 2017) 
masih rendah dikarenakan bagi hasil yang di tawarkan kurang menguntung bagi masyarakat/nasabah.

\section{Teori/Kajian}

a. Al-Mudharabah (Profit Sharing)

Mudharabah berasal dharb (ضر ب), yang mempunyai arti memukul atau berjalan. Pengertian memukul atau berjalan ini lebih tepatnya adalah proses seseorang memukulkan kakinya dengan menjalankan usaha. Secara teknis, al-Mudharabah adalah akad kerja sama usaha antara dua pihak dimana pihak pertama (shahihibul maal) menyediakan seluruh modal, sedangkan pihak lainnya (Mudharib) menjadi pengelola. Keuntungan usaha secara mudharabah dibagi menurut kesepakatan yang dituangkan dalam kontrak, sedangkan apabila rugi ditanggung oleh pemilik modal selama kerugian itu bukan akibat kelalaian si pengelola. Seandainya kerugian itu diakibatkan karena kecurangan atau kelalaian si pengelola, si pengelola harus bertanggung jawab atas kerugian tersebut. ${ }^{6}$

Bagi hasil menurut terminologi asing (bahasa Inggris) dikenal dengan profit sharing. Profit dalam kamus ekonomi diartikan pembagian laba. Secara definisi profit sharing diartikan distribusi beberapa bagian dari laba pada pegawai dari suatu Perusahaan. ${ }^{7}$

Pada Bank Syari'ah terdapat sebuah pembagian keuntungan dengan sistem bagi hasil atau sering disebut dengan nisbah. Nisbah merupakan ratio atau perbandingan, yang didalam dunia perbankan pembagian keuntungan (bagi hasil) antara pemilik dana dengan pengelola dana. ${ }^{8}$

Sistem bagi hasil merupakan sistem dimana dilakukannya perjanjian atau ikatan bersama di dalam melakukan kegiatan usaha. Di

${ }^{6}$ Muhammad Syafii Antonio. Bank Syariah: Dari Teori Ke Praktik, (Jakarta: Gema Insani, 2001), Cet. 1. h. 95.

${ }^{7}$ Muhammad. Manajemen Bank Syariah, (Yogyakarta: (UUP) AMP YKNP, 2005), h. 105.

${ }^{8}$ Pelaayanan Bank syariah. Penjelasan Mengenai Nisbah di Bank Syariah, http:// www .syariahbank.com/penjelasan-mengenai-nisbah-di-bank-syariah/ diakses (9 Agustus 2017) 
dalam usaha tersebut diperjanjikan adanya pembagian hasil atas keuntungan yang akan di dapat antara kedua belah pihak. Bagi hasil dalam sistem perbankan Syari'ah merupakan ciri khusus yang ditawarkan kepada masyarakat, dan di dalam aturan Syari'ah yang berkaitan dengan pembagian usaha harus ditentukan terlebih dahulu pada awal terjadinya kontrak (akad). Besarnya penentuan porsi bagi hasil antara kedua belah pihak ditentukan sesuai kesepakatan bersama, dan harus terjadi adanya kerelaan (An-Tarodhin) di masingmasing pihak tanpa adanya unsur paksaan.

b. Minat Nasabah

Minat Nasabah adalah suatu rasa lebih suka dan rasa keterkaitan pada suatu hal atau aktifitas tanpa ada yang menyuruh, minat beli merupakan suatu proses pengambilan keputusan yang dilakukan oleh konsumen. ${ }^{9}$

Faktor-faktor yang mempengaruhi perilaku konsumen dalam membeli barang dan jasa perusahaan adalah ${ }^{10}$ :

1) Faktor Lingkungan Ekstern

Perilaku konsumen sangat dipengaruhi berbagai lapisan masyarakat di mana ia dilahirkan dan dibesarkan. Ini berarti konsumen yang berasal dari lapisan masyarakat atau lingkungan yang berbeda akan mempunyai penilaian, kebutuhan, pendapat, sikap, dan selera yang berbeda-beda.

2) Faktor Lingkungan Intern

Selain faktor lingkungan ekstern, faktor Psikologis yang berasal dari proses intern individu, sangat berpengaruh terhadap perilaku pembelian konsumen. Teori-teori psikologis akan banyak membantu dalam memberikan pengetahuan yang sangat penting tentang alasanalasan menyangkut perilaku konsumen.

Selain itu juga Swastha dan Irwan mengemukakan bahwa aspekaspek yang terdapat dalam minat beli antara lain :

a) Ketertarikan (Interest) yang menunjukkan adanya pemusatan perhatian dan perasaan senang.

9 Komarudin, Kamus Perbankan, (Jakarta:Grafindo ,1994), h. 94.

${ }^{10}$ Swastha dan Irwan. Perilaku Konsumen, (Bandung:Alfabeta, 2001), h. 95. 
b) Keinginan (desire) ditunjukkan dengan adanya dorongan untuk ingin memiliki.

c) Keyakinan (conviction) ditunjukkan dengan adanya perasaan percaya diri individu terhadap kualitas, daya guna, dan keuntungan dari produk yang akan dibeli. ${ }^{11}$

Minat nasabah adalah sumber motivasi yang mendorong seseorang untuk melakukan apa yang ingin dilakukan ketika bebas memilih, ketika seseorang menilai bahwa sesuatu bisa bermanfaat, maka bisa menjadi berminat, kemudian hal tersebut bisa mendatangkan kepuasan, ketika kepuasan menurun maka minatnya juga bisa menurun. Sehingga minat tidak bersifat permanen, tetapi minat bersifat sementara atau dapat berubah-ubah.

Jadi dapat disimpulkan bahwa minat nasabah adalah motivasi nasabah untuk melakukan atau menilai suatu produk dalam bank sehingga mendatangkan kepuasan.

c. Tabungan BSM

Tabungan adalah Simpanan berdasarkan Akad wadi'ah atau Investasi dana berdasarkan Akad mudharabah atau Akad lain yang tidak bertentangan dengan Prinsip Syari'ah yang penarikannya hanya dapat dilakukan menurut syarat dan ketentuan tertentu yang disepakati, tetapi tidak dapat ditarik dengan cek, bilyet giro, dan/atau alat lainnya yang dipersamakan dengan itu. ${ }^{12}$

Tabungan BSM adalah Tabungan dalam mata uang rupiah yang penarikan dan setorannya dapat dilakukan setiap saat selama jam kas dibuka di konter BSM atau melalui ATM. ${ }^{13}$

1) Manfaat Tabungan BSM

a) Aman dan terjamin

b) Online di seluruh outlet BSM

c) Bagi hasil yang konpetitif

d) Fasilitas BSM Card yang berfungsi sebagai kartu ATM \& debit

${ }^{11}$ Ibid, h. 95.

${ }^{12}$ Republik Indonesia. “Undang-Undang Nomor 21 Tahun 2008 Tentang Perbankan Syariah” (Ketentuan Umum, Jakarta: 2008), h. 5.

${ }^{13}$ Brosur Bank Syariah Mandiri Muara Bungo 
e) Fasilitas e-Banking, yaitu BSM Mobile Banking \& BSM Net Banking

f) Kemudahan dalam penyaluran zakat, infaq dan sedekah

2) Persyaratan: Kartu identitas (KTP/SIM/Paspor) nasabah

3) Karakteristik Tabungan BSM

a) Berdasarkan prinsip Syari'ah dengan akad mudharabah muthlaqah

b) Minimum setoran awal: Rp 80.000 (perorangan)

c) Minimum setoran berikutnya: Rp 10.000

d) Saldo minimum: Rp 50.000

e) Biaya tutup rekening: $\mathrm{Rp} 20.000$

f) Biaya administrasi Rp 6.000

4) Contoh Perhitungan Tabungan BSM

Saldo rata-rata pak Sarman bulan Agustus 2008 adalah Rp 1 juta. Perbandingan bagi hasil (nisbah) antara bank dan nasabah adalah 66:34. Bila saldo rata-rata tabungan seluruh nasabah BSM pada agustus 2008 adalah Rp 70 milyar dan pendapatan bank yang dibagihasilkan untuk nasabah tabungan adalah Rp 6 milyar maka bagi hasil yang diperoleh pak sarman adalah $=\mathrm{RP} \quad 1.000 .000$ /70.000.000.000 × 6.000.000.000 × 34\% = 29.143 (sebelum dipotong pajak)

\section{Tujuan Penulisan}

Dalam penelitian ini penulis terdapat beberapa tujuan yang dikemukan, yaitu:

1. Untuk mengetahui apa saja yang jadi problem bagi Bank Syariah Muara Bungo

2. Untuk menaganalisis seberapa besar dampak marjin bagi hasil terhadap minat nasabah menabung di Bank Syaria Muara Bungo

\section{B. METODOLOGI}

1. Metodologi Penelitian

Pada penelitian ini jenis yang digunakan adalah penelitian Deskriptif Kuantitatif. Metode deskriptif adalah metode statistik yang menitikberatkan pada pengumpulan penyajian, pengolahan serta 
peringkasan data yang mana aktivitas ini tidak berlanjut pada penarikan kesimpulan. Sedangkan metode kuantitatif adalah penelitian yang menggunakan instrument bervariasi agar data yang terkumpul dapat lengkap, akurat, dan rinci dengan sumber data yang banyak tetapi tidak harus mendalam. ${ }^{14}$ Untuk memudahkan proses penelitian maka peneliti menggunakan Software Computer SPSS 16.0

Populasi adalah wilayah generalisasi yang terdiri atas obyek/subyek yang mempunyai kualitas dan karakteristik tertentu yang ditetapkan oleh peneliti untuk dipelajari dan kemudian ditarik kesimpulannya. ${ }^{15}$

Populasi dalam penelitian adalah Nasabah Bank Syari'ah Mandiri Muara Bungo khusus nasabah tabungan BSM. Dengan jumlah keseluruhan nasabah tabungan BSM di Bank Syari'ah Muara Bungo yaitu sebanyak 6000 nasabah. ${ }^{16}$

Sampel adalah bagian dari jumlah dan karakteristik yang dimiliki oleh populasi tersebut. ${ }^{17}$ Untuk menentukan besaran sampel, peneliti menggunakan rumus Slovin. Oleh karena mengingat waktu, tenaga, dan kemungkinan adanya hambatan-hambatan, maka penulis mengambil sampel dengan besaran 10\%. Jumlah sampel yang diambil dengan menggunakan rumus Slovin sebagai berikut:

$\mathrm{n}=/\left(1=\mathrm{N} .(\mathrm{e})^{2}\right)$

Keterangan :

$\mathrm{n}$ = Jumlah Sampel

$\mathrm{N}=$ Jumlah Populasi

e = Tingkat kesalahan yang masih bisa ditolerir

Maka dalam penelitian ini, sampel penelitian yang diperoleh dari populasi sebanyak 6000 nasabah, dengan tingkat kesalahan sebesar $10 \%$ adalah sebagai beriut :

$\left.\mathrm{n}=6.000 /(1+6.000) \cdot(10 \%)^{2}\right)$

${ }^{14}$ Purbayu Budi Santosa dan Muliawan Hamdani, Statistika Deskriptif Dalam Bidang Ekonomi dan Niaga, (Jakarta: Erlangga, 2007), h. 7.

${ }^{15}$ Suryabrata, Sumadi. Metodologi Penelitian. (Jakarta: Alfabeta 2011), h. 90.

${ }^{16}$ Wawancara Dengan Arie Kurniawan Customer Service, Dan Sandy Kurniadi Mantan Customer Service. Bank Syariah Mandiri Muara Bungo, (23Agustus 2017)

${ }^{17}$ Suryabrata, Sumadi. Metodologi Penelitian.h. 91. 


$$
\begin{aligned}
& \left.\mathrm{n}=6.000 /(1+6.000) \cdot(0.1)^{2}\right) \\
& \mathrm{n}=6.000 /(1+6.000) \cdot(0.01)) \\
& \mathrm{n}=6.000 /(1+60) \\
& \mathrm{n}=6.000 / 61 \\
& \mathrm{n}=99 \text { nasabah }
\end{aligned}
$$

Jadi, sampel yang diperoleh dari populasi sebesar 6.000 nasabah Tabungan BSM adalah 98,36 maka digenapkan menjadi 99 nasabah.

Penelitian ini Menggunakan teknik Analisis regresi linear sederhana digunakan untuk memprediksi atau menguji pengaruh satu variabel bebas atau variabel independent terhadap variabel terikat atau variabel dependent, Untuk memudahkan peneliti menggunakan SPSS 16.0. Bila skor variabel bebas diketahui maka skor variabel terikatnya dapat diprediksi besarnya. Analisis regresi juga dapat dilakukan untuk mengetahui linearitas variabel terikat dengan variabel bebasnya Analisis regresi linear sederhana terdiri dari satu variabel bebas (predictor) dan satu variabel terikat (respon) dengan persamaan:

$$
\mathrm{Y}=\mathrm{a}+\mathrm{bX}+\mathrm{e}
$$

Keterangan :

Variabel dependen adalah:

$\mathrm{Y}=$ Tabungan BSM

Variabel independen adalah:

$\mathrm{X}=$ Bagi hasil

$\mathrm{a}=$ Bilangan konstanta

$\mathrm{b}=$ Koefisien arah regresi

$\mathrm{e}=$ Error

Langkah-langkah untuk melakukan teknik analisis ini adalah:

a. Uji Validitas

Validitas adalah suatu ukuran yang menunjukkan tingkatantingkatan kevalidan dan kesahihan suatu instrumen. ${ }^{18}$

b. Uji Realibilitas

Realibilitas adalah alat untuk mengukur suatu kuesioner yang merupakan indikator dari variabel atau konstruk. Butir pernyataan dikatakan reliable atau handal apabila jawaban seseorang terhadap

${ }^{18}$ Ibid. h. 137. 
pernyataan adalah konsisten. Suatu konstruk atau variabel dikatakan reliable jika memberikan nilai cronbach alpha $>0.60$, namun ada yang menggunakan 0.70 atau 0.90 tergantung tingkat kesulitan data dan peneliti. ${ }^{19}$

\section{c. Uji Normalitas}

Uji normalitas data adalah hal yang lazim dilakukan sebelum sebuah metode statistik. Uji normalitas merupakan salah satu bagian dari uji persyaratan analisis data atau biasa disebut asumsi klasik. Tujuan uji normalitas adalah untuk mengetahui apakah distribusi sebuah data mengikuti atau mendekati distribusi normal, yakni distribusi data yang mampunyai pola seperti distribusi normal. ${ }^{20}$

\section{Hipotesis Penelitian}

Hipotesi penelitian adalah suatu jawaban sementara terhadap perrmasalahan penelitian sampai terbukti melalui data yang terkumpul $^{21}$. Sehubungan dengan permasalahan penelitian ini yaitu mengenai Pengaruh Bagi Hasil Terhadap Minat Nasabah Pada Tabungan BSM di Bank Syariah Mandiri Muara Bungo Maka hipotesis yang diajukan dalam penelitian ini adalah:

a. Ha: Diduga bagi basil berpengaruh terhadap minat nasabah pada tabungan BSM diperbankan syari'ah.

b. Ho : Diduga bagi hasil tidak berpengaruh terhadap minat nasabah pada tabungan BSM diperbankan syari'ah.

\section{Pembahasan}

\section{Temuan Penelitian}

Deskriptif Variabel digunakan untuk menganalisa data dengan cara mendeskriptifkan atau menggambarkan data yang telah terkumpul, sebagaimana adanya tanpa bermaksud membuat

${ }^{19}$ Danang Sunyanto, Metodologi Penelitian Akuntansi, (Bandung:PT Refika Aditama, 2013), h. 81.

${ }^{20}$ Raharjo, Sahid Uji Normalitas Kolmogorov-Smirnov dengan SPSS http : / / www .spss indonesia . com diakses (28 September 2017)

${ }^{21}$ Suharsimi Arikunto. Prosedur Penelitian Suatu Pendekatan Praktek, (Jakarta: Rineka Cipta, 2006), h. 110. 
kesimpulan yang bersifat umum atau generalisasi tabel di bawah ini menunjukkan hasil olahan data statistik deskriptif:

a. Hasil Uji Validitas

1) Variabel Bagi hasil (X)

Tabel 1. Uji Validitas X

\begin{tabular}{|c|c|c|c|}
\hline $\begin{array}{c}\text { Item } \\
\text { Pernyataan }\end{array}$ & Rhitung & Rtabel & Interpretasi \\
\hline 1 & 0,794 & 0,165 & VALID \\
\hline 2 & 0,692 & 0,165 & VALID \\
\hline 3 & 0,753 & 0,165 & VALID \\
\hline 4 & 0,558 & 0,165 & VALID \\
\hline 5 & 0,694 & 0,165 & VALID \\
\hline 6 & 0,482 & 0,165 & VALID \\
\hline 7 & 0,405 & 0,165 & VALID \\
\hline
\end{tabular}

Dari tabel diatas Dapat disimpulkan bahwa semua pernyataan $r$ hitungnya lebih besar dari $\mathrm{r}$ tabel sebesar 0.165 , maka semua butir pernyataan adalah valid.

2) Variabel Tabungan BSM (Y)

Tabel 2. Uji Validitas Y

\begin{tabular}{|c|c|c|c|}
\hline $\begin{array}{c}\text { Item } \\
\text { Pernyataan }\end{array}$ & rhitung & Rtabel & Interpretasi \\
\hline 1 & 0,510 & 0,165 & VALID \\
\hline 2 & 0,648 & 0,165 & VALID \\
\hline 3 & 0,687 & 0,165 & VALID \\
\hline 4 & 0,597 & 0,165 & VALID \\
\hline 5 & 0,500 & 0,165 & VALID \\
\hline 6 & 0,584 & 0,165 & VALID \\
\hline 7 & 0,571 & 0,165 & VALID \\
\hline
\end{tabular}

Dari tabel diatas Dapat disimpulkan bahwa semua pernyataan $r$ hitungnya lebih besar dari $\mathrm{r}$ tabel sebesar 0.165 , maka semua butir pernyataan adalah valid. 
b. Hasil Uji Realibilitas

1) Variabel Bagi Hasil

Tabel 3. Reliability Statistics

\begin{tabular}{|c|c|}
\hline Cronbach's Alpha & N of Items \\
\hline .738 & 7 \\
\hline
\end{tabular}

Dari tabel diatas dari output nilai alpha $0,738>0,6$, sehingga dapat disimpulkan untuk item-item angket dapat dikatakan reliable atau terpercaya sebagai alat pengumpulan data dalam penelitian.

2) Variable Tabungan BSM

Tabel 4. Reliability Statistics

\begin{tabular}{|c|c|}
\hline Cronbach's Alpha & N of Items \\
\hline .667 & 7 \\
\hline
\end{tabular}

Dari tabel diatas dari output nilai alpha $0,667>0,6$, sehingga dapat disimpulkan untuk item-item angket dapat dikatakan reliable atau terpercaya sebagai alat pengumpulan data dalam penelitian.

c. Model Analisis dan Uji Asumsi Klasik

1) Uji Normalitas

Uji Normalitas adalah sebuah uji yang dilakukan dengan tujuan untuk menilai sebaran data pada sebuah kelompok data atau variabel, apakah sebaran data tersebut berdistribusi normal ataukah tidak. Uji Normalitas berguna untuk menentukan data yang telah dikumpulkan berdistribusi normal atau diambil dari populasi normal. 
Gambar 1. Uji Normalitas

Normal p-P plot of Regression Standardized Residual

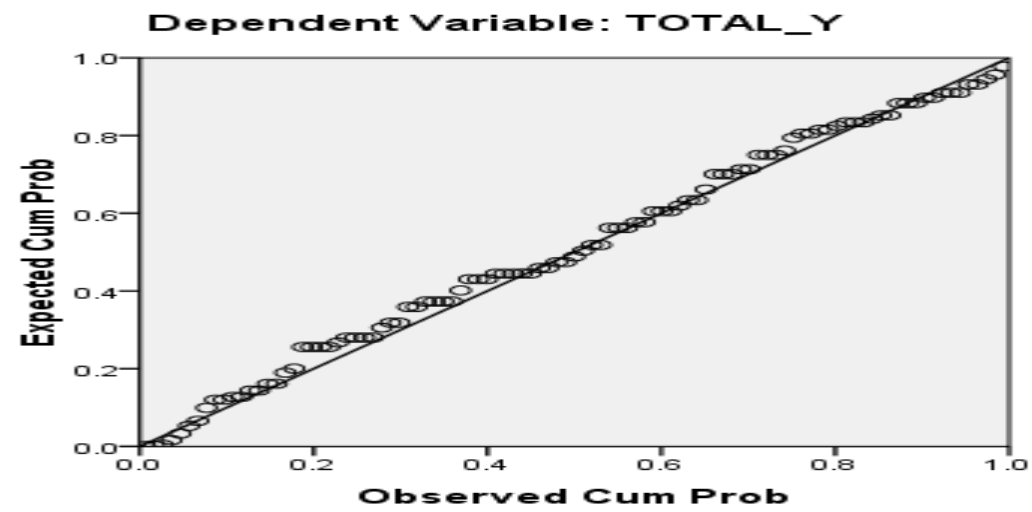

Untuk lebih menjelaskan gambar diatas maka harus dilakukan uji Kolmogorov Smirnov untuk mengetahui data berdistribusi normal.

Tabel 5: One-Sample Kolmogorov-Smirnov Test

\begin{tabular}{|ll|r|}
\hline & & $\begin{array}{c}\text { Unstandardized } \\
\text { Residual }\end{array}$ \\
\hline $\mathrm{N}$ & & 99 \\
Normal Parameters & Mean & .0000000 \\
& Std. Deviation & 2.99007698 \\
Most Extreme Differences & Absolute & .073 \\
& Positive & .038 \\
& Negative & -.073 \\
Kolmogorov-Smirnov Z & & .726 \\
Asymp. Sig. (2-tailed) & & .668 \\
\hline
\end{tabular}

a. Test distribution is Normal.

b. Calculated from data.

Berdasarkan uji normalitas dengan uji Kolmogorov-Smirnov (KS) Test diperoleh nilai Asymp.sig. sebesar 0,668 lebih besar dari 0,05. Karena nilai sig lebih besar dari 0,05, maka keputusannya adalah 
menerima Ho yang berarti bahwa data berdistribusi normal. Berarti asumsi normalitas data terpenuhi.

2) Analisis Regresi Linier Sederhana

Analisis regresi digunakan terutama untuk tujuan peramalan, dimana dalam model tersebut ada sebuah variabel dependen (tergantung) dan variabel independen (bebas). Analisis regresi linear sederhana adalah analisis untuk mengukur besarnya pengaruh antara satu variabel dependen dengan menggunakan variabel independen.

Tabel 6. Hasil Regresi Linier Sedehana

Coefficients $^{\mathrm{a}}$

\begin{tabular}{|c|r|r|r|r|r|}
\hline \multirow{2}{*}{ Model } & \multicolumn{2}{|c|}{$\begin{array}{c}\text { Unstandardized } \\
\text { Coefficients }\end{array}$} & $\begin{array}{c}\text { Standardized } \\
\text { Coefficients }\end{array}$ & \multirow{2}{*}{$\mathrm{T}$} & \multirow{2}{*}{ Sig. } \\
\cline { 2 - 4 } & \multicolumn{1}{|c|}{$\mathrm{B}$} & Std. Error & \multicolumn{1}{|c|}{ Beta } & & \\
\hline (Constant) & 22.981 & 1.856 & & 12.385 & .000 \\
Bagi_Hasil & .222 & .077 & .282 & 2.890 & .005 \\
\hline
\end{tabular}

a. Dependent Variable:

Tabungan_BSM

Variabel tergantung pada regresi ini adalah tabungan BSM (Y) sedangkan Variabel bebasnya adalah bagi hasil (X). Model regresi ( $\mathrm{Y}=$ a $+\S \mathrm{x})$ Berdasarkan hasil analisis di atas adalah sebagai berikut:

$\mathrm{Y}=22.981+0.222 \mathrm{x}$

Dari analisis regresi di atas dapat diketahui bahwa nilai konstan (a) adalah 22.981. Nilai ini menunjukkan bahwa pada saat bagi hasil (X) bernilai 0, maka tabungan BSM (Y) akan bernilai 22.981.

Sedangkan nilai beta (ß) negatif yaitu sebesar 0.222 yang menyatakan bahwa apabila bagi hasil 0 maka akan bernilai negatif. Artinya satu-satuan skor tabungan BSM dipengaruhi oleh variabel lain.

3) Uji T

Uji T dipergunakan untuk melihat signifikan tidaknya masingmasing variabel bahi hasil (X), terhadap tabungan BSM (Y). 
Tabel 7. Uji T

\begin{tabular}{|c|r|r|r|r|r|}
\hline \multirow{2}{*}{ Model } & \multicolumn{2}{|c|}{$\begin{array}{c}\text { Unstandardized } \\
\text { Coefficients }\end{array}$} & $\begin{array}{c}\text { Standardized } \\
\text { Coefficients }\end{array}$ & \multirow{2}{*}{$\mathrm{T}$} & \multirow{2}{*}{ Sig. } \\
\cline { 2 - 4 } & \multicolumn{1}{|c|}{$\mathrm{B}$} & \multicolumn{1}{|c|}{ Std. Error } & \multicolumn{1}{c|}{ Beta } & & \\
\hline (Constant) & 22.981 & 1.856 & & 12.385 & .000 \\
Bagi_Hasil & .222 & .077 & .282 & 2.890 & .005 \\
\hline
\end{tabular}

a. Dependent Variable:

Tabungan_BSM

Ha = Bagi hasil Bank Syari'ah mempunyai pengaruh yang positif dan signifikan terhadap minat nasabah pada tabungan BSM

Ho = Bagi hasil Bank Syari'ah tidak mempunyai pengaruh yang positif dan signifikan terhadap minat nasabah pada tabungan BSM

Pengambilan keputusan:

Jika nilai $\mathrm{t}$ hitung $\geqslant \mathrm{t}$ tabel, maka Ho ditolak dan Ha diterima , artinya signifikan.

Jika nilai t hitung $\leqslant \mathrm{t}$ tabel, maka Ho diterima dan Ha ditolak, artinya tidak signifikan.

Berdasarkan tabel 7. di atas dapat dilihat bahwa bagi hasil (X) Pada variabel independen tingkat bagi hasil ditemukan bahwa nilai dari t hitungnya sebesar 2,890.

Nilai t tabel dihitung berdasarkan rumus:

Tingkat signifikan $\alpha / 2=5 \%(0,05 / 2=0,025)$

Dk (derajat kebebsan) $=\mathrm{n}-2=99-2=97$

maka diperoleh nilai t tabel sebesar 1,985 .

Karena nilai t hitung lebih besar dari t tabel yaitu 2,890 > 1,985 dengan ini berarti menerima $\mathrm{Ha}$ dan menolak Ho. Hal ini menunjukkan adanya pengaruh bagi hasil terhadap tabungan BSM di Bank Syari'ah Mandiri Muara Bungo.

4) Analisis Koefisien Determinasi

Koefisien determinasi ( $\mathrm{R}$ Squuare) pada intinya mengukur seberapa jauh kemampuan model dalam menerapkan variasi variabel dependen. Melaui koefisien determinasi (R Square) dapat diketahui sejauh mana variabel bagi hasil di Bank Syari'ah (X) memberikan 
dampak terhadap tabungan BSM. Semakin nilai 1 atau 100\% maka semakin besar dampak bagi hasil Bank Syari'ah terhadap variabel dependen.

Tabel 8. Analisis Koefisien Determinasi

Model Summary

\begin{tabular}{|l|r|r|r|r|}
\hline Model & \multicolumn{1}{|c|}{$\mathrm{R}$} & R Square & $\begin{array}{c}\text { Adjusted R } \\
\text { Square }\end{array}$ & $\begin{array}{r}\text { Std. Error of } \\
\text { the Estimate }\end{array}$ \\
\hline 1 & $.282^{\mathrm{a}}$ & .079 & .070 & 3.005 \\
\hline
\end{tabular}

a. Predictors: (Constant), Bagi_Hasil

b. Dependent Variable: Tabungan_BSM

Berdasarkan hasil destimasi model persamaan regresi yang telah dilakukan di atas diperoleh nilai koefisien korelasi sebesar 0.282 ini artinya bahwa tingkat bagi hasil memiliki hubungan dengan tabungan BSM sebesar 28,2\% sedangkan nilai koefisien determinasi $\mathrm{R}$ Square sebesar 0, 079 atau (7,9\%). Hal ini menunjukkan bahwa persentase sumbangan pengaruh variabel independen (bagi hasil Bank Syari'ah) terhadap variabel dependen (tabungan BSM) sebesar 7,9\%, sedangkan 92,1\% dipengaruhi atau dijelaskan oleh variabel lain yang tidak dimasukkan dalam model penelitian ini.

\section{Pembahasan}

a. Bagi Hasil Memberi Pengaruh Positif Terhadapa Produk Tabungan BSM

Tahap pertama yang dilakukan dalam penelitian ini adalah menganalisis data dengan uji validitas dan reliabilitas dari jawaban responden yang diperoleh melalui kuesioner berjumlah 99 orang. Hasil dari uji ini menyatakan bahwa semua butir pernyataan dinyatakan valid dan reliabel untuk diuji dalam penelitian ini. Tahap selanjutnya melakukan analisis koefisien determinasi ( $\mathrm{R}$ Square) dengan angka $\mathrm{R}$ Square sebesar 0,079 atau 7,9\%. Hal ini menunjukkan bahwa bagi hasil Bank Syari'ah Mandiri Muara Bungo terhadap tabungan BSM Sebesar 7,9\%, sedangkan 92,1\% diperkembangkan oleh variabel lain yang tidak dimasukkan dalam model penelitian ini. 
b. Minat Nasabah Pada Produk Tabungan BSM

Berdasarkan Pengujian regresi linear Sederhana Bahwa bagi hasil dengan minat nasabah pada tabungan BSM nasabah memiliki hubungan yang positif yaitu $28 \%$. Hal ini terjadi karena tingkat bagi hasil dominan mempengaruhi minat menabung nasabah.

untuk mengetahui ada tidaknya pengaruh dan variabel bagi hasil (X) terhadap variabel tabungan BSM (Y), hasil penelitian menunjukkan variabel bebas (bagi hasil) signifikan terhadap minat nasabah pada tabungan BSM sebesar 0,005.

Dalam penelitian Wirdayani Wahab, Bahwa tingkat bagi hasil berpengaruh secara signifikan terhadap minat menabung nasabah. Tingkat bagi hasil adalah hal yang begitu dominan dalam mendorong seseorang nasabah dalam membuka rekening tabungan di bank syariah. ${ }^{22}$

Dari berbagai studi dapat disimpulkan bahwa faktor utama mempengaruhi tabungan BSM adalah bagi hasil yang di tawarkan oleh Bank Syari'ah kepada nasabah. Besar bagi hasil yang ditawarkan oleh Bank Syari'ah mandiri adalah salah satu faktor utama nasabah berminat menabung di Bank Syari'ah mandiri Muara Bungo khususnya produk tabungan BSM. Hal ini menunjukan ketika keinginan nasabah terhadap produk tersebut terpenuhi maka nasabah mengambil keputusan untuk menggunakan produk yang memberikan keuntungan bagi mereka. Itu artinya peningkatan jumlah nasabah di bank syriah mandiri Muara Bungo akan bertambah dikarenakan bagi hasil yang diberikan oleh Bank Syari'ah memberi dampak positif kepada masyarakat Muara bungo.

Selain itu kualitas pelayanan yang diberikan, strategi pemasaran yang digunakan ataupun atribut produk perbankan yang ditawarkan perlu dipertimbangkan dalam meningkatkan minat menabung nasabah pada bank syariah mandiri. Selain itu hal yang harus dipertimbangkan oleh bank syariah mandiri adalah memberikan kualitas pelayanan yang prima kepada nasabah, namun tidak

${ }^{22}$ Wirdayani Wahab, Pengaruh Tingkat Bagi Hasil Terhadap Minat Menabung Di Bank Syariah, vol. 1, Nomor. 2, h 16. 
mengabaikan kebijakan mengenai tingkat bagi hasil yang ditawarkan ke nasabah.

Dalam sebual teori perilakukonsumen bahwa Minat Nasabah adalah suatu rasa lebih suka dan rasa keterkaitan pada suatu hal atau aktifitas tanpa ada yang menyuruh, minat beli merupakan suatu proses pengambilan keputusan yang dilakukan oleh konsumen. ${ }^{23}$

Faktor-faktor yang mempengaruhi perilaku konsumen dalam membeli barang dan jasa perusahaan adalah ${ }^{24}$ :

\section{a. Faktor Lingkungan Ekstern}

Perilaku konsumen sangat dipengaruhi berbagai lapisan masyarakat di mana ia dilahirkan dan dibesarkan. Ini berarti konsumen yang berasal dari lapisan masyarakat atau lingkungan yang berbeda akan mempunyai penilaian, kebutuhan, pendapat, sikap, dan selera yang berbeda-beda.

b. Faktor Lingkungan Intern

Selain faktor lingkungan ekstern, faktor Psikologis yang berasal dari proses intern individu, sangat berpengaruh terhadap perilaku pembelian konsumen. Teori-teori psikologis akan banyak membantu dalam memberikan pengetahuan yang sangat penting tentang alasanalasan menyangkut perilaku konsumen.

Selain itu juga Swastha dan Irwan mengemukakan bahwa aspekaspek yang terdapat dalam minat beli antara lain :

a. Ketertarikan (Interest) yang menunjukkan adanya pemusatan perhatian dan perasaan senang.

b. Keinginan (desire) ditunjukkan dengan adanya dorongan untuk ingin memiliki.

c. Keyakinan (conviction) ditunjukkan dengan adanya perasaan percaya diri individu terhadap kualitas, daya guna, dan keuntungan dari produk yang akan dibeli. ${ }^{25}$

Minat nasabah adalah sumber motivasi yang mendorong seseorang untuk melakukan apa yang ingin dilakukan ketika bebas

${ }^{23}$ Komarudin, Kamus Perbankan, (Jakarta:Grafindo ,1994), h. 94.

${ }^{24}$ Swastha dan Irwan. Perilaku Konsumen, (Bandung:Alfabeta, 2001), h. 95.

${ }^{25}$ Ibid, h. 95. 
memilih, ketika seseorang menilai bahwa sesuatu bisa bermanfaat, maka bisa menjadi berminat, kemudian hal tersebut bisa mendatangkan kepuasan, ketika kepuasan menurun maka minatnya juga bisa menurun. Sehingga minat tidak bersifat permanen, tetapi minat bersifat sementara atau dapat berubah-ubah.

Jadi dapat disimpulkan bahwa minat nasabah adalah motivasi nasabah untuk melakukan atau menilai suatu produk dalam bank sehingga mendatangkan kepuasan tersendiri bagi nasabah.

\section{Kesimpulan}

Berdasarkan hasil penelitian yang peneliti lakukan maka dapat disimpulkan Bahwa pengaruh bagi hasil Bank Syari'ah terhadap tabungan BSM yaitu signifikan. Bagi hasil yang ditetapkan oleh Bank Syari'ah mandiri memiliki pengaruh terhadap minat nasabah pada Bank Syari'ah mandiri Muara Bungo. Hal ini ditujukan dengan pengujian hipotesis berdsarkan perbandingan uji t hitung dengan uji $t$ tabel. diperoleh hasil nilai $\mathrm{t}$ hitung $>\mathrm{t}$ tabel $(2,890>1,985)$ dan signifikasi $<0,05(0,005<0,05)$, maka Ho ditolak, sehingga terbukti terdapat pengaruh antara bagi hasil terhadap tabungaan BSM. Kofisien korelasi yang ditemukan sebesar 0,282 dan termasuk kategori rendah. Jadi terdapat hubungan yang rendah antara bagi hasil dengan tabungan BSM. Dan ditemukan bahwa hasil nilai koefesien determinasi ( $\mathrm{R}$ Square) sebessar 0,079 artinya bahwa bagi hasil berpengaruh terhadap tabungan BSM sebesar 7,9\% sedangkan sisanya sebesar 92,1\% dipengaruh oleh variabel lain yang tidak diketahui dan tidak termasuk dalam penelitian ini.

\section{Daftar Pustaka}

A.Karim Adiwarman. Bank Islam: Analisis Fiqih dan Keuangan, Jakarta: PT Raja Grafindo Persada, 2010.

Abdullah M.Faisal. Manajemen Perbankan Teknis Analisi Kinerja Keuangan Bank, Malang: UMM, 2003, cet. 3. 
Arikunto Suharsimi. Prosedur Penelitian Suatu Pendekatan Praktek, Jakarta: Rineka Cipta, 2006.

Brosur Bank Syariah Mandiri Muara Bungo

Budi Santosa Purbayu dan Muliawan Hamdani, Statistika Deskriptif Dalam Bidang Ekonomi dan Niaga, Jakarta: Erlangga, 2007.

Edwin Prasstio, Pengaruh Tingkat Nisbah Bagi Hasil, Penerapan Akad, Citra Merek, Promosi, Dan Kualitas Pelayanan Terhadap Minat Menabung Pada Lembaga Keuangan Perbankan Syariah, Skripsi UIN Syarif Hidayatullh 2017, h. 94

Irwan dan Swastha. Perilaku Konsumen, Bandung:Alfabeta, 2001.

Komarudin. Kamus Perbankan, Jakarta:Grafindo ,1994.

Muhammad. Manajemen Bank Syariah, Yogyakarta: (UUP) AMP YKNP, 2005, hal. 105

Pelaayanan Bank syariah. Penjelasan Mengenai Nisbah di Bank Syariah, http:// www .syariahbank.com/penjelasan-mengenainisbah-di-bank-syariah/ diakses 9 Agustus 2017

Republik Indonesia. “Undang-Undang Nomor 21 Tahun 2008 Tentang Perbankan Syariah” Ketentuan Umum, Jakarta:2008, h. 5

Republik Indonesia. "Undang-Undang R.I. Nomor 10 Tahun 1998 Tentang Perbankan Syariah", Perubahan Atas Undang-Undang Nomor 7 Tahun 1992 Tentang Perbankan. Ketentuan Umum, Jakarta: 1998, h. 3

Sahid Raharjo Uji Normalitas Kolmogorov-Smirnov dengan SPSS http : / / www .spss indonesia . com. diakses 28 September 2017

Sumadi Suryabrata. Metodologi Penelitian. Jakarta: Alfabeta 2011.

Sunyanto Danang. Metodologi Penelitian Akuntansi, Bandung:PT Refika Aditama, 2013.

Syafii Antonio Muhammad. Bank Syariah: Dari Teori Ke Praktik,. Jakarta: Gema Insani , 2001, Cet. 1 
Wawancara Dengan Arie Kurniawan Customer Service, Dan Sandy Kurniadi Mantan Customer Service. Bank Syariah Mandiri Muara Bungo, 23 Agustus 2017

Wawancara Dengan Fajri Kanda Branch Operation and Service Manager, Ari. A. Irawan Micro Banking Manager dan Sandy Kurniadi Mantan Customer Service. Bank Syariah mandiri Muara Bungo, 23Agustus 2017

Wirdayani Wahab, Pengaruh Tingkat Bagi Hasil Terhadap Minat Menabung Di Bank Syariah, vol. 1, Nomor. 2, h 16 